\title{
Insufficient Implementation of Wastewater Disposal and Municipal Waste Recycling in Healthcare Facilities in Serbia
}

\author{
BRANISLAVA I. MATIĆ, Institute of Public Health of Serbia \\ "Dr Milan Jovanović Batut", Belgrade \\ VERICA S. JOVANOVIĆ, Institute of Public Health of Serbia \\ "Dr Milan Jovanović Batut", Belgrade \\ LjILjANA M. JOVANOVIĆ, Ministry of Health of Serbia, \\ Belgrade \\ RADMILA M. ŠEROVIĆ, Ministry of Agriculture and \\ Environment Protection, Belgrade \\ UROŠ D. RAKIĆ, Institute of Public Health of Serbia \\ "Dr Milan Jovanović Batut", Belgrade
}

Previous announcement

UDC: 628.4.046(497.11)

628.316(497.11)

\begin{abstract}
Besides acquiring health services, healthcare facilities present a substantial environmental health risk through diagnostics, therapeutic and laboratory practice. Wastewaters from these procedures are a heterogeneous mixture including toxic chemicals, microorganisms, radioisotopes and hormones. Our aim was to point at the existing flaws in managing liquid waste within the all-level healthcare system in Serbia. Cross-section study was implemented in a sample of 45 facilities. Questionnaire was used as a survey tool focusing on wastewater treatment and laboratory analysis. Pretreatment is implemented in only three facilities, while in 9 out of 45(20\%) facilities regular laboratory tests of the efluent are practiced. Within the sample of 212 facilities questioned for municipal waste recycling practice, 50\% recycles all streams available for recycling, while 50\% does not include this process into its regular daily agenda.
\end{abstract}

Key words: wastewaters, municipal waste, healthcare facilities, risk

\section{INTRODUCTION}

Healthcare facilities are institutions offering certain kind of health services, from the observational (check-ups), diagnostic, testing, therapeutical and rehabilitation domain, with its primary role in maintaining health and wellbeing of a certain population group [1]. In Serbia, health protection is provided through a wide range of different institutions, by type and scope of services, at three organizational levels: primary (primary health centers with ambulances, PHCs), secondary (general hospitals), and tertiary level of health protection in specialized hospitals, clinical-hospital centers (3 in Belgrade City), university clinics, clinical centers (4 in the country) [2]. Among numerous health

Author's address: Branislava Matić, Institute of $\mathrm{Pu}$ blic Health of Serbia "Dr Milan Jovanović Batut", Belgrade, Dr Subotića starijeg 5, brankicam@batut.org.rs

Paper received: 25.01.2017.

Paper accepted: 03.02.2017. services generating hazardous waste effluents, special microbiological and research laboratories are institutions with a substantial fraction in its amount and nature of polluting substances. Contamination of natural aquatic ecosystems due to irregular disposal of hospital wastewaters is an important issue for environment and health protection, overall [3].

Moreover, with the public's increasing demands on healthcare standards, advancements in medical technology and rapid development in the pharmaceutical sciences, the number and complexity of hospital activities have increased and thus have led to more negative impacts through the increase in wastewater production by hospitals. [1, 3]. Pollutants of concern present in hospital wastewater belong to different groups, such as antibiotics, X-ray contrast agents, heavy metals, disinfectants, detergents, solvents, pharmaceuticals, and some radionuclide [4]. About 10-25\% of the volume of healthcare waste from hospitals and healthcare institutions worldwide presents a serious 
health hazard to patients, healthcare workers, and anybody who comes in contact with it [5].

The hazardous wastes are those that may cause ill health or increase mortality in humans, fauna, and flora or adversely affect the environment when improperly treated, stored, transported, or disposed of $[5,6,7]$. Hazardous wastes are normally produced in labor wards, operation theatres, and laboratories $[8,9]$. The remaining $75 \%$ to $90 \%$, which is generated from offices, kitchens, and housekeeping sections, is nonhazardous and poses no risk of infection transmission, as it is comparable to domestic wastes [10, 11].

The dosage of pollutants of hospital origin shows certain substances, such as anti-tumor agents, antibiotics and organ halogen compounds, leave mostly wastewater treatment plants [12]. By leaving the wastewater treatment plants, these chemical compounds can provoke the pollution of the natural environment by entailing a biological imbalance. In case the environmental conditions allowing the degradation of these substances are not gathered, they can exercise negative effects on the receiving waters and the living species [13].

In developing countries, the average demand for water by hospitals is $500 \mathrm{~L}$ per bed per day [14]. In addition to this high demand for drinking water is the requirement for specific waters such as physiological solution, sterilized water and serums [15].This consumption of water by hospitals, which far exceeds the minimum household consumption of $100 \mathrm{~L}$ per inhabitant per day, gives rise to large volumes of wastewater [16].

Managing wastewaters in Republic of Serbia is defined through: Directive on limit values of pollutants' emissions into waters and timeframe for reaching targets, By-law on parameters of environmental and chemical status of surface waters and parameters of chemical and quantitative status of groundwater, and Law on water quality as a basic legal framework $[17,18,19]$. Until now, there were no thorough studies of hospital wastewater quality in Serbia.

Key objective of this article is to point at the flaws and ineffectiveness of the process of managing wastewater disposal within the health system in Republic of Serbia, as well as to indicate at the low coverage of the municipal waste recycling practice in institutions already implementing an accredited and licensed healthcare waste management Plan.

\section{METHODS AND DATA COLLECTION}

This article wraps up outcomes of two separate cross/sectional studies on the issue of assessing coverage of final disposal of healthcare wastewater, together with implementation of municipal waste reczcling practice in healthcare facilities in the Republic of Serbia. Both studies were designed and performed by the healthcare waste management (HCWM) Team of the Institute of Public Health of Serbia (IPHS). Legal framework for this kind of research activities gives the IPHS jurisdiction upon following public health concerns: environmental health, sanitary inspection, protection of population from infectious diseases, waste management [2, 22-25]. Since Serbia has introduced proper healthcare waste management in 2007, IPHS was given a coordinating and consultative role for the overall spectre of activities concerning hazardous healthcare waste streams specifically [20, 26, 27].

Sample for the disposal of wastewater study comprised of 45 healthcare facilities. As a survey tool we used a questionnaire, focusing on water pre-treatment and laboratory analysis of wastewater effluents. Questionnaire was distributed to state-owned HCFs from the Plan of the HCFs Network, as defined by the Ministry of Health [28]. Primary healthcare centers (PHCs), general hospitals, clinical centres and institutes of public health were categories of facilities involved in the study. Data base was designed according to the questionnaire. Questions to be answered by professionals managing waste in the facilities, focused on type and number of laboratory units, disposal of wastewaters, eventual implementation of a pre-treatment process prior to final disposal to the sewage, physicochemical analysis of wastewater quality on regular basis. This pilot-study was conducted in 2016 .

Besides analysis of final wastewater disposal practice from healthcare facilities, this article aims to assess coverage of municipal waste recycling in this kind of institutions. A cross-sectional study was conducted by the IPHS HCWM Team (20). As a survey instrument we used a database formed in the process of evaluation of HCWM Plans, fulfilling its assignment given by the Ministry of Health, containing quantitative data relevant for the HCWM process in Serbia, such as recycling capacities, amount of generated waste, by specific waste streams, handling municipal wasre, etc. Key study tool was a document Healthcare Waste Management Plan produced by healthcare facilities generating more than $500 \mathrm{~kg}$ of hazardous waste/year, according to the Law on waste management [25]. Data collection, analysis and processing was implemented strictly by a list of topics defined by the specific by-law [29]. For the mapping of spatial distribution of healthcare facilities that participated in the study, GIS (Geographic Information Systems) methodology was used.

\section{RESULTS}

45 healthcare facilities from the surveyed sample are spatially distributed in 19 administrative districts 
and the capital City of Belgrade, as a special administrative unit (Figure 1). Altogether, questionnaires were replied by 20 Primary Health Centers (PHCs), 13 hospital institutions ( 3 at the tertiary level of healthcare) and 12 IPHs. In total, 74 laboratories function in these 45 facilities, as shown in Table 1.

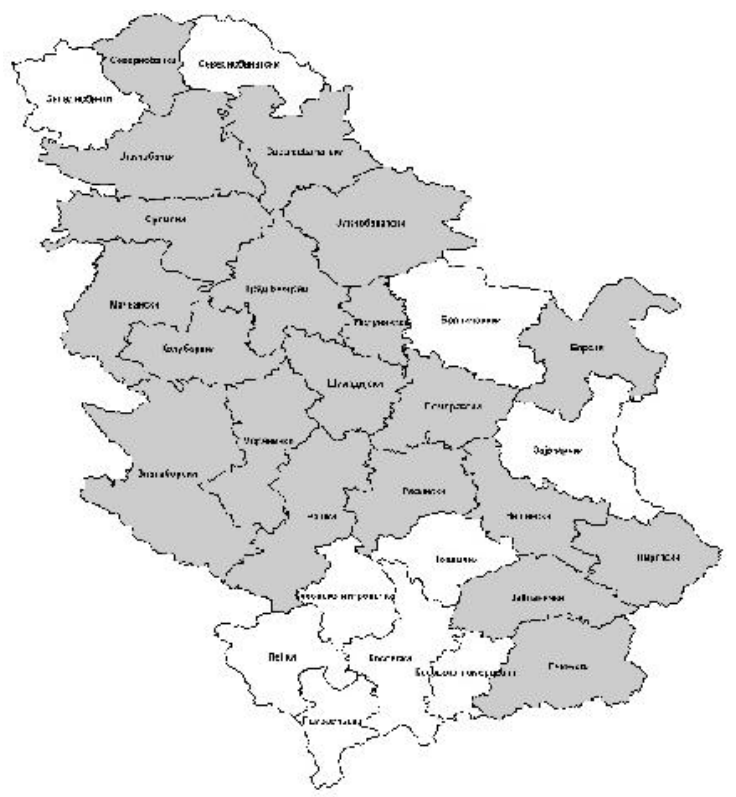

Figure 1 - Spatial distribution of institutions from the study

Table 1. Distribution of labs by type of healthcare facility

\begin{tabular}{|c|c|c|c|c|c|}
\hline \multirow{2}{*}{$\begin{array}{l}\text { Type of } \\
\text { facility }\end{array}$} & \multirow{2}{*}{$\mathrm{N}$} & \multicolumn{3}{|c|}{ Laboratory type } & \multirow{2}{*}{ Total } \\
\hline & & MB & $\mathrm{BC}$ & ETox & \\
\hline Hospitals & 13 & 11 & 13 & l & 24 \\
\hline PHCs & 20 & 7 & 14 & I & 21 \\
\hline IPHs & 12 & 12 & 5 & 12 & 29 \\
\hline Total & 45 & 30 & 32 & 12 & 74 \\
\hline
\end{tabular}

MB - microbiology BC - Biochemistry ETox - Ecotoxicology

In line with the national legislation, ecotoxicological and microbiological diagnostics are mandatory activities of network of Institutes of Public Health (IPHs), while, having a biochemistry lab within the local Institute of Public Health is practiced according toactual neads of the health sector planning at the local level $[2,18]$.

This explains tha fact that some IPHs have all three kinds of labs, while, on the other hand, some PHCs have only a biochemical lab, as in this particular local level there is an Institute of Public Health with an obligatory presence of a microbiology lab. Spatial distribution of the network of Institutes of Public Health in the Republic of Serbia is shown in Figure 2.

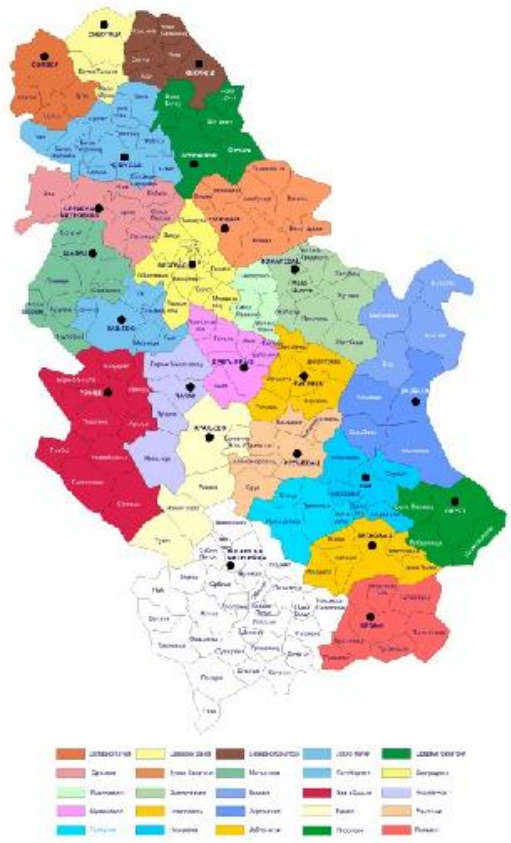

Figure 2 - Spatial distribution of IPHs in Serbia

In investigating coverage of healthcare wastewater disposal in healthcare facilities from the study, questionnaire focused on: disposal of wastewater straight into sewage with/without any pre-treatment process, eventual neutralization of toxic and hazardous chemicals generated in laboratory practice prior to its disposal into the drain. And, finally, regular physicochemical check-up analysis of the effluent were taken into consideration. Results of this analysis are given in Figure 3.

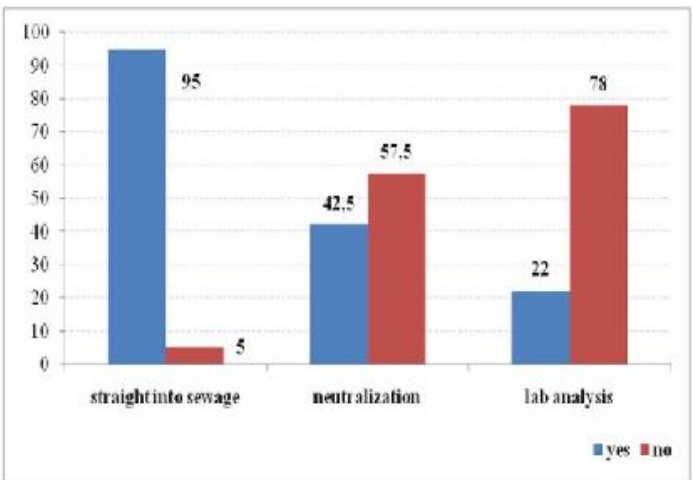

Figure 3 - Wastewater disposal in healthcare facilities in total sample (\%)

Analyzing the whole sample of 45 institutions, majority $(95 \%)$ disposes of its wastewater straight into municipal sewage. As for the neutralization of toxical liquids from the labs, situation is semi-satisfactory (42.5:57.5\%), while the laboratory analysis of wastewaters on regular basis is performed in only one fifth of the surveyed facilities. If we fracture the whole sample by the type of facilities. of 13 hospitals only one of them perform pre-treatment of wastewater prior to 
its disposal into sewage (7.7\%). Wastewater from all 20 PHCs and 12 IPHs involved in the study flows straight into the sewage system with no pre-tratment. As for the neutralization of laboratory toxic effluents prior to the drain, in 3 out of 13 hospitals (23\%) this process is provided, as is done in 3 out of $20 \mathrm{PHCs}$ (15\%) and 9 out of 12 IPHs (75\%). Regular physicochemical and microbiological analysis of wastewater is performed in only 9 out of total 45 participating healthcare facilities (20\%), namely, in 2/13 hospitals, 2/20 PHCs and 5/12 IPHs.

One of the elements of the HCWM Plan analyzed in this study is establishment of continuous and organized practice of recycling municipal waste, generated in healthcare institutions. Results are presented in Figure 3.

Among „special hospitals“ Serbian legislation recognizes health resorts for treatment of specific ailments and deteriorating health disorders, together with hospitals aimed only for clinical treatment of lung and kidney diseases, or pediatric care, for example. As we presented in Figure 4, it is clear that recycling of municipal waste is far more present in PHCs and IPHs, than in special and general hospitals. Namely, out of 39 general hospitals recycling is present only in 11 $(28,2 \%)$; among 51 general hospitals it is done in only 21 of them $(41,2 \%)$. On the other hand, municipal waste recycling is much better organized in PHCs and IPHs, meaning that in 59 out of $117(50.43 \%)$ of PHCs waste is recycled, as well as in 15 of 23 IPHs (65.2\%) participating in the study.

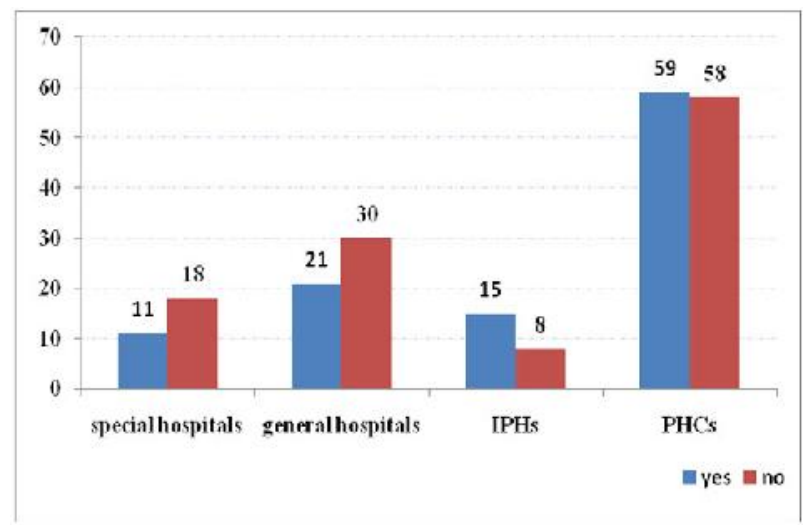

Figure 4 - Coverage of recycling practice

\section{DISCUSSION}

Strategy for strengthening the engagement of the health sector in the implementation of the Strategic Approach to International Chemicals Management (SAICM), has been adopted at the Third Session of the International Conference on Chemicals Management in 2012, in Nairobi, Kenya. Although Republic of Serbia has approved this innitiative, which is, in fact, oragizationally supported by the World Health
Organization, health sector is yet lacking its initial steps in implementing basic principles of the SAICM [30].

Results acquired in this study indicate that managing disposal of wastewaters generated in health sector is in no way on the agenda of priorities when regular activities within this sector are taken into account. On the other hand, knowing that some healthcare facilities finance regular monitoring and analysis of wastewater quality opens a window of oportunity for further responsible and environmentally sound management within the health sector, which should be followed by others and appreciated by the Ministry of Health. From results of studies involving chemical analyses of hospital wastewaters in other countries, several key parameters are chosen to be constantly monitored as indicators of potential risk for the environmental balance of the recipient media, as well as for the health of exposed population [31]. Namely, indicators of this kind include: $p$ value, electrical conductance, chlorides, total suspended solids, chemical and biochemical requirement of oxygen (COD, BOD), lead, nickel, total chromium, and faecal coliform bacteria [3133].

Recycling municipal waste in health facilities is a more of a success story, compared to wastewater disposal. Ratio of number of facilities practicing or not practicing recycling is 50\%:50\% (106:106), indicating to the nessecity of establishing regular training of those managing healthcare institutions, on the issues of recycling process, together with its financial benefits for these legal entities. Also, implementing recycling practice within health system, actually strengthens law enforcement strategies, above all the Law on waste management and Law on environmental protection.

\section{CONCLUSIONS}

As Republic of Serbia is deeply involved in the EU pre-accession process, with an inevitable opening of Chapter 27 (environmental protection) on the way, issues of wastewater management and treatment should be approached through a series of concrete activities, among which regulating disposal of wastewater from healthcare facilities is just a minor segment. Fact that public health sector, together with its network of IPHs is legally responsible for environmental health impact assessment of population exposed to harmful substances, gives a perfect example of necessity for multisectorial approach in resolving issues of public health importance. The authors recommend that Serbian government imposes environmental legislations in which each hospital should have effective wastewater treatment unit, thus protecting both the recipient environmental media and health of the potentially exposed population. 


\section{REFERENCES}

[1] Kumar M, Mathur N, Singh A, Sharm P, Genotoxic Hazard of healthcare Wastewater: A Review; Int.J.Curr.Microbiol.App.Sci, vol 3(10): 409-418 (2014).

[2] кон о з штити здр вљ (,, лужбени гл сник“ , број 15/2016).

[3] Al-Ajlouni K, Shakhatreh S, Al-Ibraheem N, Jawarneh M, Evaluation of Wastewater Discharge from Hospitals in Amman-Jordan. International Journal of Basic \& Applied Sciences IJBAS-IJENS, 2013; 13(04), $44-50$.

[4] Dana S, Monica P, Daniela C, Andrel, A.C, Ludovic $\mathrm{H}, 2005$. Environmental risk of hospital wastewater. CEJOEM. 11(4), 281-88.

[5] World Health Organization (WHO), Management of Solid Healthcare Waste at Primary Healthcare Centre-A Decision-Making Guide, World Health Organization (WHO), Geneva, Switzerland, 2005, http://www.who.int/water sanitation health/ publications/manhcwm.pdf.

[6] Dinesh M. S, Geetha K. S, Vaishmavi V, Kale R. D, Krishna-Murthy V, "Ecofriendly treatment of biomedical wastes using epigeic earthworms," Journal of the Indian Society of Hospital Waste Management, vol. 9 (1): 5-20, 2010.

[7] Johannessen L. M, Dijkman M, Bartone C, Hanrahan D, Boyer G. M, Chandra C, "Healthcare waste management guidance note," HNP Discussion Paper, Health Nutrition and Population, The International Bank for Reconstruction and Development/TheWorld Bank, 2000.

[8] Msuya J. M, Nyaruhucha C. N. M, Kaswahili J, "Does preventive health care have a chance in the changing health sector in Tanzania?" East African Medical Journal, vol. 80 (3): 135-139, 2003.

[9] Mohankumar S, Kottaiveeran K, "Hospital waste management and environmental problems in India," International Journal of Pharmaceutical and Biological Archive, vol. 2 (6):1621-1626

[10]Srinivasa C. V, "MedicalWasteManagement Practices in urban India and Strategies for safe disposal," in Proceedings of the Southern Regional Conference on Biomedical Waste Management, TamilNadu Pollution Control Board, Chennai, India, 2001

[11]Pruss A, Giroult E, and Rushbrook P, Safe Management of Wastes from Healthcare Activities, Handbook, World Health Organisation, Geneva, Switzerland, 1999. ISBN 9241545259
[12]Chitnis V, Chitnis S, Vaidyaa K, Ravi kant S, Patil S.and Chitnis D. S, Bacterial population changes in hospital effluent treatment plant in central India, Wat. Res., 2004, 38: 441-447

[13]Chitnis V, Chitnis D.S, Patil S.and Ravi Kant S, Hospital effluent: a source of multiple drug resistant bacteria. Curr. Sci., 2000, 79: 989-91.

[14]Laber J, Raimund H, Shrestha R, Two-stage constructed wetland for treating hospital wastewater in Nepal. Water Sci Technol 1999; 40: 317-24.

[15]Emmanuel E, Blanchard, J. M, Keck, G, Perrodin Y, Caractérisation chimique, biologique et écotoxicologique des effluents hospitaliers. Déchets Sciences et Techniques, revue francophone d'écologie industrielle, 2001, 22:31-33.

[16]Gadelle F, Le monde manquera-t-il bientôt d'eau? Sécheresse, 1995, vol. 6: 11-15.

[17]Regulation on limit values for emissions of pollutants in water and deadlines for their achievement (Official Gazette RS, No 67/2011, 48/2012).

[18]Rule book on the parameters of the ecological and chemical status of surface waters and the parameters of chemical and quantitative status of groundwater (Official Gazette RS, No 30/2010).

[19]Water Quality Act (Official Gazette RS, No 30/10, 93/12).

[20]Matić B, Jovanović V, Knežević S, Uloga institucija javnog zdravlja u praćenju procesa upravljanja medicinskim otpadom, prezentovan na skupu: "Farmaceutski i medicinski otpad i održivi razvoj" 2. Savetovanje sa međunarodnim učešćem, Sremski Karlovci, 19-20.05.2015. Zbornik radova: 36-42 ISBN 978-86-80809-98-4

[21]Matić B, Jovanović V, Jovanović Lj, Šerović R, Wastewater disposal in Healthcare Facilities in Serbia; 37. Stručno-naučni skup "Vodovod i kanalizacija", 11-14.10.2016. Vrdnik, Srbija; Zbornik radova: 239-246. ISBN 9786-86-80067-34-6

[22]Law on Public Health (Official Gazette RS, No $15 / 2016)$

[23]Law on Sanitary Inspection („Official Gazette“ RS, No 125/2004)

[24]Law on the protection of the population against infectious diseases (Official Gazette RS, No 15/2016)

[25]Law on Waste Management (Official Gazette RS, No $36 / 2009,88 / 2010,14 / 2016$ )

[26]Jovanović Verica S, Gerrit Tesink Jan B, Jovanović Dragomir V, Đonović Nela Ž, Jevtić Marija R, Matić Branislava I, Šerović Radmila M, Development of 
Healthcare Waste Management in Serbia and Challenges in the Improvement of the Quality of Healthcare Services, Tehnika - kvalitet IMS, Standardizacija i metodologija; 2014, vol. 69 (2): 343-348

[27]Šerović R. M, Jelić IV, Antonijević DLj, Adžemović MR, Vujović ZR, Jovanović VS, Matić IM, Generisanje i upravljanje medicinskim otpadom u Srbiji pregled. Tehnika - kvalitet IMS, Standardizacija i metodologija; 2016; 16(3): 487-493.

[28]Regulation on Health Institutions Network Plan (,Official Gazette“ RS, No 92/2015)

[29]By-law on healthcare waste management ( лужбени гл сник“, број 92/2015)

[30]Strategy for strengthening the engagement of the health sector in the implementation of the Strategic Approach to International Chemicals Management, http://www.who.int/ipcs/saicm/health_sector_strateg y.pdf

[31]Mahmoudkhani R, Mokhtari Azar A, Reza Khani M, A Survey of Tehran Hospitals Wastewaters; 2012 International Conference on Future Environment and Energy, IPCBEE vol 28 (2012); IACSIT Press, Singapore

[32]Ekhaise F.O, Omavwoya B. P, Influence of Hospital Wastewater Discharged from University of Benin Teaching Hospital (UBTH), BeninCity on its Recieving Environment; American-Euroasian J. Agric\&Environ.Sci. 4(4): 484-488, 2008.

[33]El Morhit M, Yagoubi M, Belmakki A, Zouhdi M, Monthly Physicochemical Characterization of a Hospital effluent According to Technical and Care Activities (Avicenna Rabat-Morocco). World Journal of Pharmacy and Pharmaceutical Sciences, Vol 4 (04): 247-267.

\section{REZIME \\ NEDOVOLJNO SPROVOĐENJE DISPOZICIJE OTPADNIH VODA I RECIKLAŽE KOMUNALNOG OTPADA U ZDRAVSTVENIM USTANOVAMA U SRBIJI}

Osim što obezbeđuju pružanje zdravstvenih usluga, zdravstvene ustanove predstavljaju značajni rizik za životnu sredinu $i$ zdravlje, sprovođenjem dijagnostičkih, terapeutskih i laboratorijskih procedura. Po svom sastavu, otpadne vode iz ovih aktivnosti su heterogena mešavina toksičnih hemikalija, mikroorganizama, radioizotopa i hormona. Cilj rada je da ukaže na postojeće nedostatke u upravljanju tečnim otpadom na svim nivoima zdravstvene zaštite u Srbiji. Studija preseka je sprovedena na uzorku od 45 zdravstvenih ustanova. Kao instrument istraživanja korišćen je upitnik, sa fokusom na tretman otpadnih voda i laboratorijsku analizu. Pred-tretman otpadnih voda primenjuje se u samo 3 ustanove, dok se u 9 od 45(20\%) ustanova vrše redovne laboratorijske analize efluenta. U uzorku od 212 ustanova ispitivanih o opsegu primene reciklaže komunalnog otpada, 50\% reciklira sve tokove otpada podobnih za reciklažu, dok $50 \%$ zdravstvenih ustanova reciklažu ne sprovodi u sklopu svojih redovnih dnevnih aktivnosti.

Ključne reči: zdravstvene ustanove, otpadne vode, komunalni otpad, reciklaža 